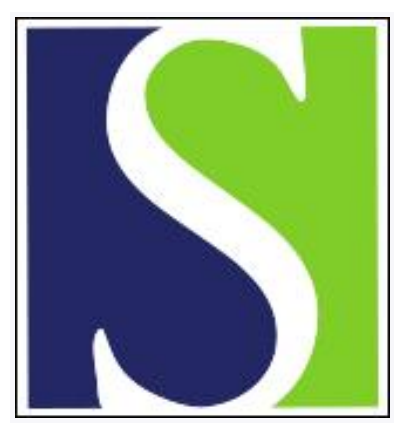

Scand J Work Environ Health 1983;9(1):42-46

https://doi.org/10.5271/sjweh.2444

Issue date: Feb 1983

Potential occupational health hazards in the microelectronics industry.

by LaDou J

This article in PubMed: www.ncbi.nlm.nih.gov/pubmed/6857187

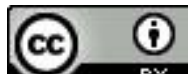




\title{
Potential occupational health hazards in the microelectronics industry
}

by Joseph LaDou, MD'

\begin{abstract}
LA DOU J. Potential occupational health hazards in the microelectronics industry. Scand $j$ work environ health 9 (1983) 42-46. The microelectronics industry is a major user of a wide variety of chemicals and other toxic materials. In the recent past semiconductor manufacturers have located in many countries and brought a new set of challenging clinical problems to occupational physicians. California, an area with a significant history in the statistical study of health and safety in the microelectronics industry, presents some evidence of potential health hazards in the semiconductor manufacturing process. The Semiconductor Industry Study done in California in 1981 explains the application of many toxic materials in the semiconductor manufacturing process, including a variety of solvents, acids, and metals such as arsenic. The Study documents the extensive use of dopant gases, primarily arsine, phosphine and diborane. Further study is necessary to assure the health and safety of microelectronics workers, particularly in the application of dopant gases.
\end{abstract}

Key terms: arsine, diborane, dopant gases, occupational illness, phosphine, semiconductor, systemic poisoning.

The microelectronics industry is rapidly becoming a major industry throughout the world. It began only 35 years ago with the development of the transistor, a small, low-power amplifier which replaced the large, inefficient vacuum tube (5). The industry found large and ready markets in the computer industry and for solid-state integrated circuits for consumer products made possible by the transistor. Today the industry produces a vast number of electronic circuits and devices for military and space agencies, the computer and data communications industries, and industrial and consumer applications.

The initial development of microelectronic devices occurred primarily in California, which today continues to lead the industry in technological advances and consumer applications. The explosive growth of this industry, stemming from a series of scientific discoveries and rapid manufacturing process developments, has resulted in a world market of more than USD 16 billion in sales and in a workforce of more than one-half

1 Department of Medicine, University of California, School of Medicine, San Francisco, California, United States.

Reprint requests to: Dr J LaDou, Peninsula Industrial Medical Clinic, $1197 \mathrm{E}$ Arques Avenue, Sunnyvale, CA 94086, USA. million. The manufacture of semiconductors and related microelectronic devices has been reviewed in the literature although state-of-the-art techniques are maintained in relative secrecy $(2,4,6,8)$.

\section{Statistical evidence of health hazards}

To date, the high technology manufacturing techniques of this industry have produced some as yet unexplained health and safety statistics in the state of California. These statistics are derived from state Workers' Compensation Insurance records from information supplied by the many hundreds of companies engaged in microelectronics manufacturing and distribution. Although the electronics industry has traditionally had a lower combined incidence of occupational illness and injury than heavier industries, workers in semiconductor manufacturing in California have consistently exhibited an unusually high incidence of occupational illness, whereas they have shown a low incidence of occupational injury. Table 1 compares the rate of injury and illness in California for all private industry, the electronics industry, and the semiconductor segment of the electronics industry. The data indicate that the electronics industry has a higher rate of occu- 
Table 1. Occupational injury and iliness rates for private-industry, electronics, and semiconductor workers.a

\begin{tabular}{|c|c|c|c|c|c|c|c|c|}
\hline & \multicolumn{4}{|c|}{$\begin{array}{c}\text { Injury and illness } \\
\text { incidence rate per } \\
100 \text { full-time employees }\end{array}$} & \multicolumn{4}{|c|}{$\begin{array}{l}\text { Occupational illness } \\
\text { incidence rate per } \\
100 \text { full-time employees }\end{array}$} \\
\hline & 1977 & 1978 & 1979 & 1980 & 1977 & 1978 & 1979 & 1980 \\
\hline $\begin{array}{l}\text { Private industry } \\
\text { Electronics industry }\end{array}$ & $\begin{array}{r}10.3 \\
7.9\end{array}$ & $\begin{array}{r}10.5 \\
8.3\end{array}$ & $\begin{array}{r}10.6 \\
8.0\end{array}$ & $\begin{array}{r}10.1 \\
7.7\end{array}$ & $\begin{array}{l}0.3 \\
0.6\end{array}$ & $\begin{array}{l}0.3 \\
0.6\end{array}$ & $\begin{array}{l}0.3 \\
0.5\end{array}$ & $\begin{array}{l}0.3 \\
0.5\end{array}$ \\
\hline $\begin{array}{l}\text { Semiconductor } \\
\text { manufacturing }\end{array}$ & 7.6 & 9.1 & 8.0 & 7.6 & 1.3 & 1.3 & 0.8 & 1.3 \\
\hline
\end{tabular}

a Data summarized from California work injuries and illnesses, Department of Industrial Relations, Division of Labor Statistics and Research, San Francisco, California, 1980, 1981 and 1982.

pational illness than other industries and that the semiconductor segment accounts for a large part of the difference.

These findings may reflect the widespread use of toxic materials in the industry, which has developed process applications for many metals, chemicals, and gases in a wide variety of combinations and environmental settings. One statistical category of occupational illness termed "systemic poisoning" is increasing each year among electronics workers engaged in semiconductor manufacturing in California. Table 2 compares the incidence of this illness among all manufacturing workers and electronics workers. The latter exhibit a large increase in this category of occupational illness, primarily because of the high incidence among semiconductor workers.

It should be emphasized that systemic poisoning includes a number of other disease possibilities and that the data cited are derived from First Report of Injury forms which seldom reflect a final medical diagnosis in complex cases of toxic exposure. Thus, rather than accurately indicating the incidence of systemic

Table 2. Systemic poisoning as the percentage of occupational illness for manufacturing, electronics, and semiconductor workers. ${ }^{a}$

\begin{tabular}{lllll}
\hline & 1977 & 1978 & 1979 & 1980 \\
\cline { 2 - 5 } & 17.8 & 19.0 & 19.2 & 19.2 \\
Manufacturing industry & 19.8 & 31.4 & 35.5 & 38.8 \\
Electronics industry & 29.8 & & & \\
$\quad \begin{array}{l}\text { Semiconductor } \\
\text { manufacturing }\end{array}$ & 37.2 & 42.9 & 42.1 & 46.9 \\
\hline
\end{tabular}

a Data summarized from California work injuries and illnesses, Department of Industrial Relations, Division of Labor Statistics and Research, San Francisco, CA, 1980, 1981 and 1982.
Table 3. Chemicals used by 42 companies manufacturing semiconductors in 1979. ${ }^{a}$

\begin{tabular}{|c|c|c|}
\hline \multirow{3}{*}{ Solvents } & \multicolumn{2}{|c|}{ Amount } \\
\hline & Kilograms & Liters \\
\hline & & 499,392 \\
\hline n-Butyl acetate & & 348,106 \\
\hline Freons & & 322,784 \\
\hline Xylene & & 280,884 \\
\hline Acetone & & 243,186 \\
\hline Methanol & & 196,100 \\
\hline Petroleum distillates & & 96,101 \\
\hline Trichloroethylene & & 86,070 \\
\hline $\begin{array}{l}1,1,1-\text { Trichlorethane } \\
\text { (methyl chloroform) }\end{array}$ & & 61,733 \\
\hline $\begin{array}{l}\text { Methylene chloride } \\
\text { (dichloromethane) }\end{array}$ & & 14,420 \\
\hline $\begin{array}{l}\text { Tetrachloroethylene } \\
\text { (perchloroethylene) }\end{array}$ & & 4,996 \\
\hline $\begin{array}{l}\text { Ethylene glycol } \\
\text { Methyl ethyl ketone }\end{array}$ & & 3,028 \\
\hline (2-butanone) & & 2,763 \\
\hline $\begin{array}{l}\text { Hexamethyldisilazane } \\
(10 \%) \text { (HMDS) }\end{array}$ & & 2,081 \\
\hline Ethanol & & 492 \\
\hline Toluene & & 227 \\
\hline Chlorobenzene & & 37 \\
\hline \multicolumn{3}{|l|}{ Acids } \\
\hline Sulfuric acid & 70,470 & $1,500,374$ \\
\hline Hydrofluoric acid & 15,390 & 786,485 \\
\hline Hydrochloric acid & 5,985 & $1,274,031$ \\
\hline Phosphoric acid & 7,560 & 122,444 \\
\hline Ammonium fluoride & 2,475 & 339,817 \\
\hline Acetic acid & 1,485 & $1,288,224$ \\
\hline Nitric acid & 2,025 & 511,959 \\
\hline Boric acid & 360 & 37 \\
\hline Citric acid & 4 & 378 \\
\hline $\begin{array}{l}\text { Buffered oxide etch } \\
\text { (hydrofluoric acid \& }\end{array}$ & & \\
\hline ammonium fluoride) & & 88,947 \\
\hline Fluoboric acid & & 302 \\
\hline \multicolumn{3}{|l|}{ Caustics } \\
\hline Sodium hydroxide & 243,045 & \\
\hline Ammonia & 39,015 & \\
\hline Potassium hydroxide & 16,051 & \\
\hline Ammonium hydroxide & 3,658 & \\
\hline
\end{tabular}

a Data summarized from pages $33-34$ of the report of Wade \& Williams (11). 
poisoning, the data merely indicate an area for suspicion about the semiconductor work environment.

\section{The semiconductor industry study}

In 1980 the California Department of Industrial Relations asked 53 semiconductor companies to provide information on their use of a large number of materials. Forty-two companies responded. This small sampling of the hundreds of semiconductor manufacturers in California included many of the major companies in the industry. Consequently the quantities of chemicals shown in table 3 are very probably indicative of the amount used overall in this segment of the electronics industry.

Table 4 indicates the types and quantities of gases and liquids that have been used widely in the manufacture of semi- conductors in recent years. The occurrence of health complaints among semiconductor workers parallels an increase in doping techniques in which arsenic, phosphorus, and boron are deposited on the surface of silicon wafers either in diffusion furnaces or by ion implantation or other advanced techniques. Dopant gases provide the dopant ions required in these processes, and arsine $\left(\mathrm{AsH}_{3}\right)$, phosphine $\left(\mathrm{PH}_{3}\right)$, and diborane $\left(\mathrm{B}_{2} \mathrm{H}_{6}\right)$ - the hydrides of arsenic, phosphorus, and boron - are being used increasingly in the semiconductor industry. These gases are usually diluted to a low concentration before the doping, but some techniques now utilize higher concentrations, which of course increase the potential for toxic exposure. Table 5 summarizes the use of these highly poisonous gases, as well as other gases commonly used, in the semiconductor industry.

Table 4. Gases and liquids used by 42 companies manufacturing semiconductors in $1979 .^{a}$

\begin{tabular}{|c|c|c|}
\hline & $\begin{array}{l}\text { Amount } \\
\text { (I) }\end{array}$ & \\
\hline \multicolumn{3}{|l|}{ Gases } \\
\hline $\begin{array}{l}\text { Hydrogen chloride } \\
\text { Unspecified concentration (probably } \\
\text { pure hydrogen chloride) } \\
5 \% \text { hydrogen chloride }\end{array}$ & $\begin{array}{r}23,657,762 \\
23,591,987 \\
65,775\end{array}$ & \\
\hline $\begin{array}{l}\text { Silane } \\
\text { Unspecified concentration (possible range } \\
1.5-100 \% \text { silane) } \\
1.5-100 \% \text { (specified) }\end{array}$ & $\begin{array}{l}7,185,035 \\
4,428,680 \\
2,756,355\end{array}$ & $(=1,750,002$ I of pure silane $)$ \\
\hline $\begin{array}{l}\text { Phosphine } \\
\text { Unspecified concentration (possible range } \\
0.0005-100 \% \text { phosphine) } \\
0.0022-10 \%\end{array}$ & $\begin{array}{l}5,990,056 \\
4,652,729 \\
1,337,326\end{array}$ & (=66,030 I pure phosphine) \\
\hline Ammonia (assumed $100 \%$ ) & $4,346,694$ & \\
\hline $\begin{array}{l}\text { Arsine } \\
\text { Unspecified concentration (possible range } \\
0.0005-100 \% \text { arsine) } \\
0.002-2 \%\end{array}$ & $\begin{array}{r}1,815,635 \\
1,305,530 \\
510,105\end{array}$ & $(=10,343 \mid$ pure arsine $)$ \\
\hline $\begin{array}{l}\text { Diborane } \\
\text { Unspecified concentration (possible range } \\
0.0005-1 \% \text { diborane) } \\
0.0023-1 \%\end{array}$ & $\begin{array}{r}750,705 \\
666,793 \\
83,912\end{array}$ & (=646 I pure diborane) \\
\hline Boron trifluoride (assumed $100 \%$ ) & 42,423 & \\
\hline Krypton 85 (assumed $100 \%$ ) & 283 & \\
\hline \multicolumn{3}{|l|}{ Liquids } \\
\hline Silicon tetrachloride (assumed $100 \%$ ) & $2,377,942$ & \\
\hline Trichlorosilane (assumed $100 \%$ ) & $1,433,793$ & \\
\hline Boron tribromide (assumed $100 \%$ ) & $1,200,930$ & \\
\hline
\end{tabular}

a Data summarized from page 35 of the report of Wade \& Williams (11). 
Table 5. Properties of gases used in semiconductor chemical vapor deposition. ${ }^{a}$

\begin{tabular}{|c|c|c|c|c|c|c|c|c|}
\hline Gas & $\begin{array}{l}\text { Flammable } \\
(\% \text { in air })\end{array}$ & $\begin{array}{l}\text { Pyrophoric } \\
\% \text { in air } \\
\text { (auto } \\
\text { ignition }{ }^{\circ} \mathrm{C} \text { ) }\end{array}$ & $\begin{array}{l}\text { Lethal in a } \\
\text { few minutes } \\
\text { (ppm) }\end{array}$ & $\begin{array}{l}\text { Lethal in a } \\
\text { few hours } \\
\text { (ppm) }\end{array}$ & $\begin{array}{c}\text { Irritant } \\
\text { level } \\
\text { (ppm) }\end{array}$ & $\begin{array}{l}\text { Approxi- } \\
\text { mate } \\
\text { odor } \\
\text { level } \\
\text { (ppm) }\end{array}$ & $\begin{array}{c}\text { 8-Hour } \\
\text { permissible } \\
\text { exposure } \\
\text { level } \\
\text { (ppm) }\end{array}$ & Comments \\
\hline $\begin{array}{l}\text { Arsine }\left(\mathrm{AsH}_{3}\right) \\
\text { Phosphine }\left(\mathrm{PH}_{3}\right) \\
\text { Diborane }\left(\mathrm{B}_{2} \mathrm{H}_{8}\right)\end{array}$ & $\begin{array}{c}\text { Yes } \\
\text { Yes } \\
0.8-88 \%\end{array}$ & $\begin{array}{c}?^{\circ} \mathrm{C} \\
40-50^{\circ} \mathrm{C} \\
37-52^{\circ} \mathrm{C}\end{array}$ & $\begin{array}{c}250 \\
2,000 \\
160 ?\end{array}$ & $\begin{array}{c}6 \\
100 \\
?\end{array}$ & $\frac{-}{8}$ & $\begin{array}{l}1 \\
2 \\
3\end{array}$ & $\begin{array}{l}0.05 \\
0.3 \\
0.1\end{array}$ & $\begin{array}{l}\text { Highly poisonous } \\
\text { Highly poisonous } \\
\text { Highly poisonous }\end{array}$ \\
\hline Ammonia $\left(\mathrm{NH}_{3}\right)$ & $15-28 \%$ & $650^{\circ} \mathrm{C}$ & 30,000 & -- & 25 & 5 & 50 & $\begin{array}{l}\text { Reacts strongly } \\
\text { with chlorides }\end{array}$ \\
\hline $\begin{array}{l}\text { Nitrous oxide } \\
\left(\mathrm{N}_{2} \mathrm{O}\right)\end{array}$ & $\begin{array}{l}\text { Supports } \\
\text { combustion }\end{array}$ & $\begin{array}{c}\text { Non- } \\
\text { pyrophoric }\end{array}$ & $?$ & - & 100 & 10 & - & $\begin{array}{l}\text { Anesthetic, possible } \\
\text { nerve damage }\end{array}$ \\
\hline $\begin{array}{l}\text { Nitrogen/dinitrogen } \\
\text { tetroxide }\left(\mathrm{N}_{2} / \mathrm{N}_{2} \mathrm{O}_{4}\right) \\
\end{array}$ & $\begin{array}{l}\text { Supports } \\
\text { combustion }\end{array}$ & $\begin{array}{c}\text { Non- } \\
\text { pyrophoric }\end{array}$ & $200 ?$ & - & 60 & 10 & $5 \mathrm{C}$ & \\
\hline Oxygen $\left(\mathrm{O}_{2}\right)$ & No & $\begin{array}{c}\text { Non- } \\
\text { pyrophoric }\end{array}$ & Nonlethal & - & - & - & - & $\begin{array}{l}\text { Keep separate from } \\
\text { reducers; supports } \\
\text { fierce combustion }\end{array}$ \\
\hline Carbon dioxide $\left(\mathrm{CO}_{2}\right)$ & No & $\begin{array}{l}\text { Non- } \\
\text { pyrophoric }\end{array}$ & Asphyxiant & 20,000 & - & - & 5,000 & Irritant \\
\hline $\begin{array}{l}\text { Silane }\left(\mathrm{SiH}_{4}\right) \\
\text { Dichlorosilane } \\
\left(\mathrm{SiH}_{2} \mathrm{Cl}_{2}\right) \text {, trichloro- } \\
\text { silane }\left(\mathrm{SiHCl}_{3}\right)\end{array}$ & $\begin{array}{l}\text { Yes } \\
\text { Yes }\end{array}$ & $\begin{array}{l}\left(0.5 \% \mathrm{SiH}_{4} / \mathrm{H}_{2}\right) \\
\left(4 \% \mathrm{SiH}_{4} / \mathrm{N}_{2}\right)\end{array}$ & Nonlethal & Nonlethal & $?$ & - & 0.5 & $\begin{array}{l}\text { Forms fine silica dust } \\
\text { and vigorous flame } \\
\text { flame }\end{array}$ \\
\hline $\begin{array}{l}\text { Silicon tetrachloride } \\
\left(\mathrm{SiCl}_{4}\right)\end{array}$ & No & - & $?$ & 8.000 & 10 & 1 & - & $\begin{array}{l}\text { Decomposes to hydrogen } \\
\text { chloride and silicon } \\
\text { dioxide in air }\end{array}$ \\
\hline Hydrogen $\left(\left(\mathrm{H}_{2}\right)\right.$ & $4-80 \%$ & $585^{\circ} \mathrm{C}$ & Asphyxiant & - & $\begin{array}{l}\text { Non- } \\
\text { irritant }\end{array}$ & $\begin{array}{l}\text { Non- } \\
\text { odorous }\end{array}$ & - & $\begin{array}{l}\text { Store }<56,678 \text { I in } \\
\text { buitding }\end{array}$ \\
\hline Nitrogen $\left(\mathbf{N}_{\mathbf{2}}\right)$ & No & - & Asphyxiant & - & $\begin{array}{l}\text { Non- } \\
\text { irritant }\end{array}$ & $\begin{array}{c}\text { Non- } \\
\text { odorous }\end{array}$ & $-\cdot$ & \\
\hline $\begin{array}{l}\text { Hydrogen chloride } \\
\text { (HCl) }\end{array}$ & No & - & 1,300 & 1,000 & 10 & 1 & 5 & Noxious \\
\hline $\begin{array}{l}\text { Hydrogen fluoride } \\
\text { (HF) }\end{array}$ & No & - & $100 ?$ & $?$ & 30 & $?$ & 3 & Noxious \\
\hline
\end{tabular}

a Data summarized from page 146 of the report of Wade \& Williams (11).

\section{Discussion}

It is a matter of concern that semiconductor manufacturers are using large quantities of the previously mentioned toxic gases in a variety of manufacturing processes and in an even wider variety of settings $(1,3,6,7,8)$. The gases are delivered in metal cylinders, and, although many hundreds of companies frequently use them, there are no uniform warning labels or uniform codes of color demarcation on the cylinders. Plant engineers and safety professionals do not agree on how the cylinders should best be handled. They must either be stored out of doors or in the work area, where they are connected to diffusion furnaces, ion implanters, or other devices by stainless steel gas lines. Some engineers feel that the cylinders should be kept outside the plant and fed into the plant by gas lines, while others argue that the safest method is to move the cylinders into the work areas and store them there.
Although semiconductor health and safety personnel consider the use of arsenic as a dopant to be an obvious health hazard, the California Industrial Relations Department survey indicates that galliumarsenide is being used increasingly as a wafer material for higher speed microelectronic devices $(3,7,9,10)$. This wider use of arsenic was studied by state investigators using industrial hygiene monitoring, and some instances of airborne contaminant levels in excess of those allowed for inorganic arsenic were disclosed. ${ }^{2}$

\section{Recommendations}

The semiconductor industry represents a major challenge to the occupational

2 A review of the 1981 Semiconductor Industry Study is beyond the scope of the present paper. Those interested may obtain a copy of the report from CalOSHA Communications, 525 Golden Gate Avenue, Third Floor, San Francisco, CA 94102, USA. 
physician. The industry and its products are of very recent origin. Moreover, the technology often moves so rapidly that new materials and processes replace old ones before sufficient information is obtained on the health hazards of either. Consequently, in cases of worker illness or injury in the semiconductor industry, occupational physicians should contact the individual's place of employment to determine from managers and supervisors the nature of the work and the conditions of the work environment. Finally occupational physicians involved in the semiconductor industry would be well advised to visit periodically the various manufacturing plants under their purview. The importance of further studies of the health and safety of microelectronics workers is evident from this early experience of the California semiconductor industry.

\section{Acknowledgments}

The author is grateful to Ms KA Jones and $\mathrm{Mr} \mathrm{AD}$ Harmon of the Division of Labor Statistics and Research, California
Department of Industrial Relations, for their technical assistance.

\section{References}

1. Elliott DJ. Integrated circuit fabrication technology. McGraw-Hill Book Co, New York, NY 1982.

2. Gise PE, Blanchard R. Semiconductor and integrated circuit fabrication techniques. Reston Publishing Company, Inc, Reston, VA 1979.

3. Kazan B. Materials aspects of display devices. Science 208 (1980) 927-936.

4. Meindl JD. Microelectronic circuit elements. Sci am 237 (1977) 70-81.

5. Noyce RN. Microelectronics. Sci am 237 (1977) 63-69.

6. Oldham WG. The fabrication of microelectronic circuits. Sci am 237 (1977) 111127.

7. Panish MB. Molecular beam epitaxy. Science 208 (1980) 916-922.

8. Penn TC. New methods of processing silicon slices. Science 208 (1980) 923-926.

9. Shank CV, Austin DH. Ultrafast phenomena in semiconductor devices. Science 215 (1982) 797-801.

10. Wade R, Williams M. Semiconductor industry study. California Department of Industrial Relations, Division of Occupational Safety and Health, Taskforce on the Electronics Industry, San Francisco, CA 1981, pp 33-34.

Received for publication: 10 November 1982 